\title{
Histopathological findings in the combined immunity-deficiency syndrome
}

COLIN L. BERRY

From Department of Morbid Anatomy, Institute of Child Health, London

SYNOPSIS The histopathological appearances of the thymus, lymph nodes, spleen, and gut- $\stackrel{\circ}{\rightarrow}$ associated lymphoid tissue (tonsil, Peyer's patches, and appendix) in cases of the combined $\frac{D}{0}$ immunity-deficiency syndrome are presented. The appearance of tissues remaining after foetal thymic transplants and the effects of such transplants on the morphology of lymph nodes are $\vec{\varphi}$ also discussed.

Although thymic appearances are remarkably constant the picture in the lymph nodes and spleen may vary considerably. The tonsils, Peyer's patches, and appendix appear to constitute one lymphoid organ in man, at least with regard to the developmental arrest that may occur in this syndrome.

In a previous study (Berry, 1968) a surprisingly high incidence of $1.8 \%$ of 1,000 thymuses showing epithelial dysplasia was demonstrated. A clinico-pathological study of these cases showed that this finding was generally associated with the so-called 'Swiss type' hypo- $\gamma$-globulinaemia (Glanzmann and Riniker, 1950) but that other varieties of combined immunity-deficiency syndromes were also seen (see Berry and Thompson, 1968).

This paper concerns the histopathological findings in the lymphoid tissues obtained by biopsy or at necropsy in a total of 31 cases of the combined immunity-deficiency syndrome seen at the Hospital for Sick Children, Great Ormond Street.

Two cases of total thymic agenesis, associated with anomalies of the aortic arch and absent parathyroid glands, are excluded. Lymphoid tissue development in these cases has been discussed recently by Dische (1968).

\section{Materials and Methods}

In 22 cases, including 14 from the original series

Received for publication 9 July 1969.
(Berry, 1968), necropsy material comprising all viscera and segments of small and large intestine were available for study. In a further four cases permission for only a limited necropsy had been obtained and blocks of thoracic viscera 3 . taken. In one instance, permission to remove a $\dot{\delta}$ grafted thymus was given but no further tissues $\frac{3}{3}$ were obtained. In five cases, surgical biopsy material was available (lymph nodes in four cases, appendix in one).

All material was formalin fixed, processed and embedded in paraffin wax and sectioned at $5 \mu \mathrm{m}$. $\sigma$

In order to assess the normal rate of histological N development of the human thymus, sections $\underset{\mathrm{N}}{\mathrm{N}}$ from 116 therapeutic abortions between 10 and 16 weeks' gestation were examined.

\section{Results}

THYMUS

Morbid anatomy

A consistent and striking feature of the 25 cases examined was the tendency of the small thymic remnant to be found largely above the innominate vein. In all instances the gland weighed less than $3 \mathrm{~g}$; in 20 cases, less than $2 \mathrm{~g}$. 


\section{Histopathology}

All glands show a strikingly similar appearance. The appearance of a simple lobular pattern of the gland, with considerable amounts of interstitial tissue that is seen early in development, persists (Figure 1). The lobules are composed of mesenchymal and epithelial cells with poor or absent cortico-medullary demarcation and paucity of lymphocytes. Hassall's corpuscles are absent or grossly reduced in numbers. In some instances, a 'glandular' or 'alveolar' pattern is seen at the periphery of the lobules (Figs. 2 and 3) but formation of a lumen is never seen. Reticulin stains show some tendency to enclose small

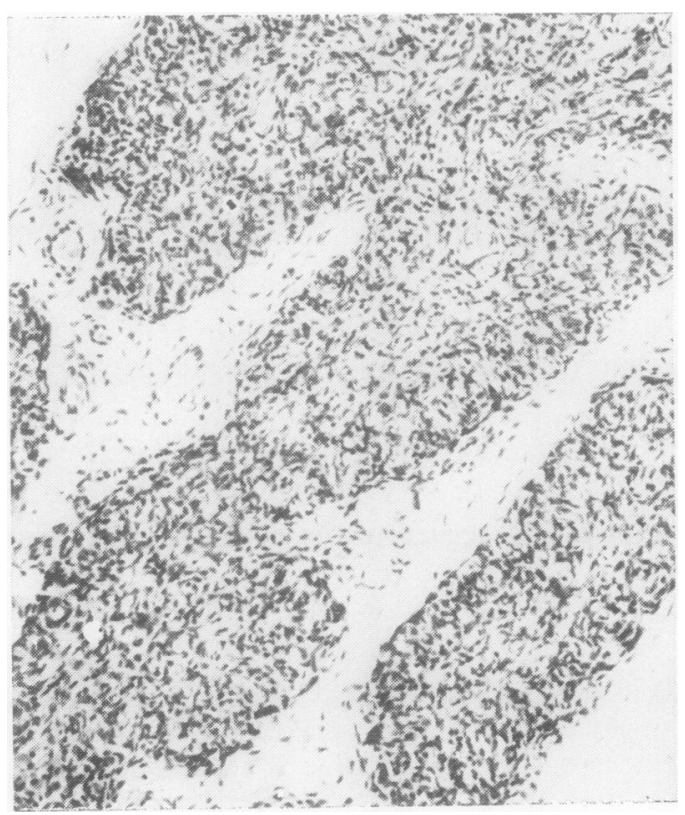

Fig. 1.

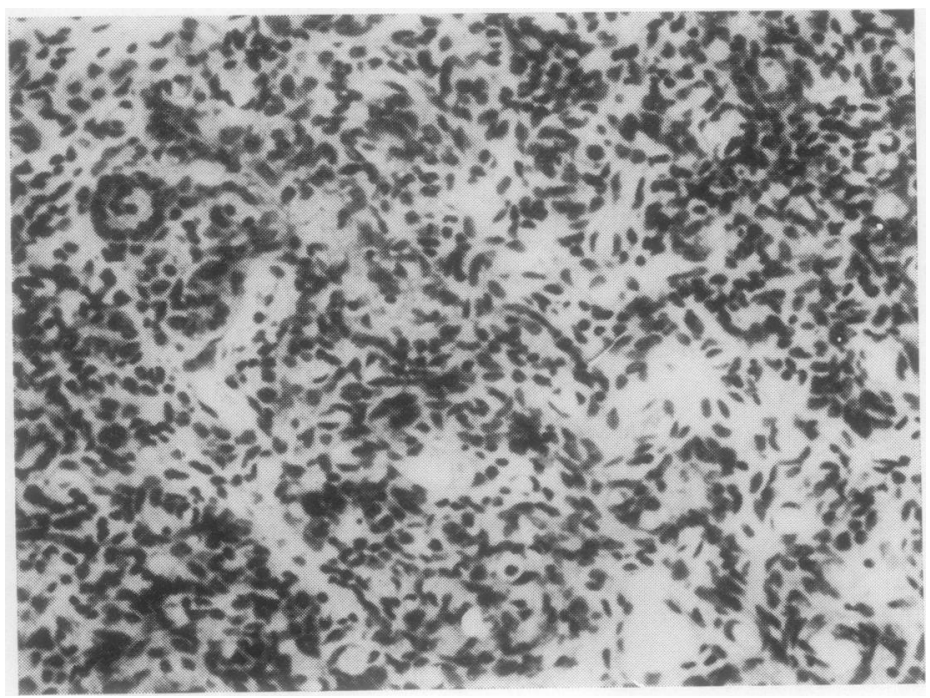

Fig. 2. peripheral groups of cells (Figure 4). In two casescthe absence of Hassall's corpuscles and a lobula? pattern was associated with gross depletion of $\bar{p}$ lymphoid tissue but with some remaining lymo phocytes seen in the putative cortex (Figure 5) Mononuclear cells were seen in the medulla.

Three foetal thymuses grafted to the anterio $\overrightarrow{\overline{\vec{G}}}$ sheath as part of reconstitutive therapy were available for study. One showed complete necrosite and organization after six weeks in situ. Th $\overline{\bar{\alpha}}$. others, after longer periods, were well maintaine $\bar{\sigma}$ and histological examination suggested thaf further development might have occurred aftef implantation (Figures 6 and 7).

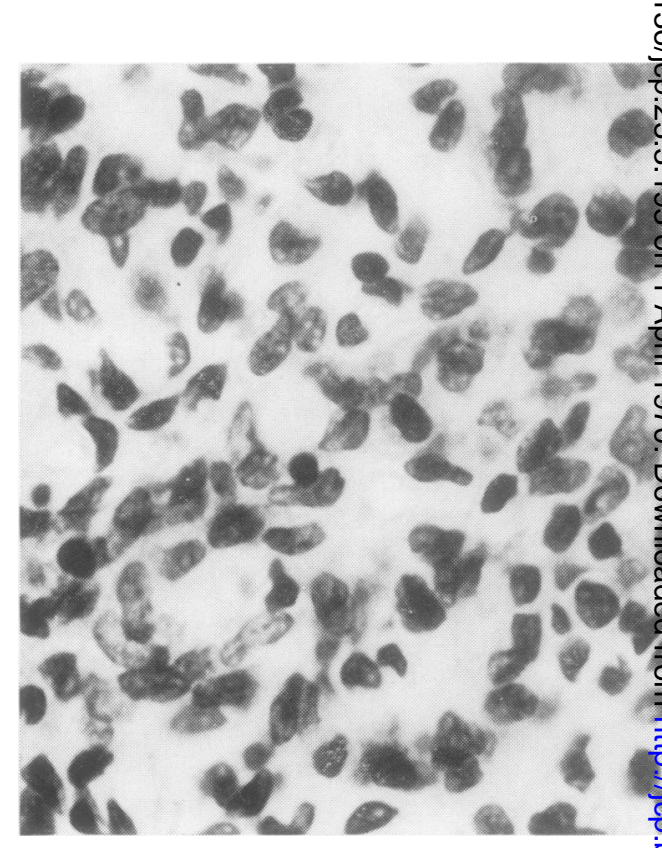

Fig. 3.

Fig. 1 Thymus: 'lobular' pattern and lack of cortico-inedullary demarcation. Haematoxylin and $\operatorname{eosin}(H \& E) . \times 40$.

Fig. 2 Thymus: alveolar pattern seen in a thymic lobule. $H \& E . \times 180$.

Fig. 3 Thymus: reticular and epithelial cells and a faty lymphocytes are seen. $H \& E . \times 480$.

Fig. 4 Thymus: reticulin pattern of thymic lobule. ₹ Gordon and Sweet. $\times 50$.

Fig. 5 Thymus: lymphocytes are seen in the prospective cortex. $H \& E . \times 50$.

Fig. 6 Foetal thymus: implanted in rectus sheath. $H \& E . \times 25$.

Fig. 7 Foetal thymus: large mononuclear cell clusters in a lobule of implanted thymus. $H \& E$. $\times 140$.

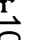




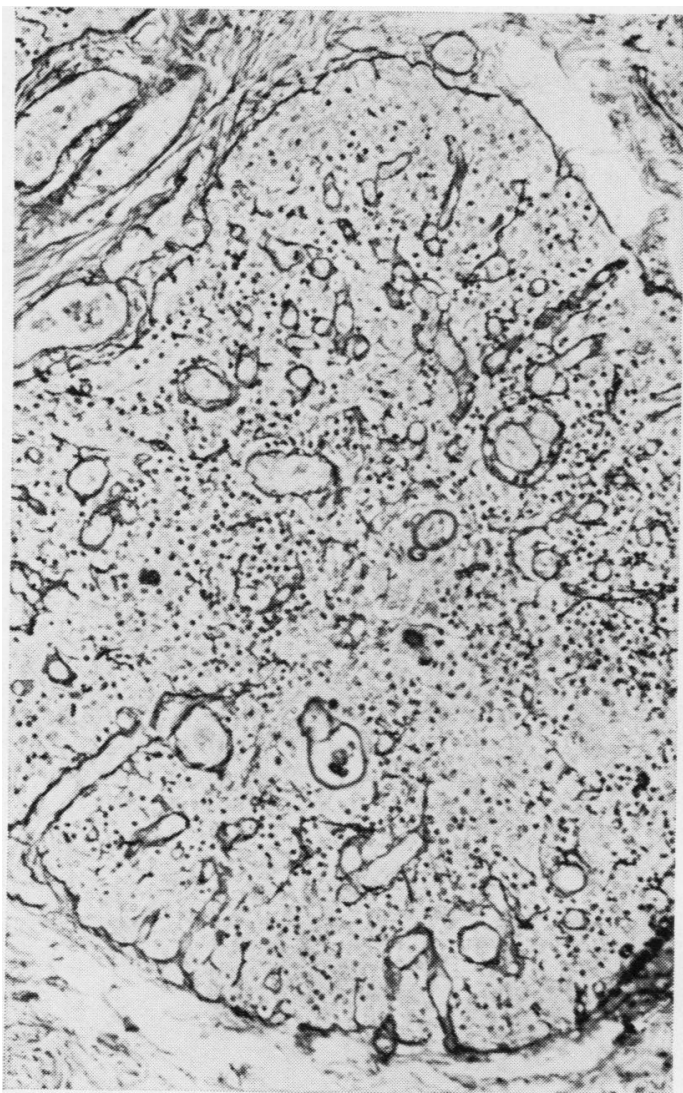

Fig. 4.

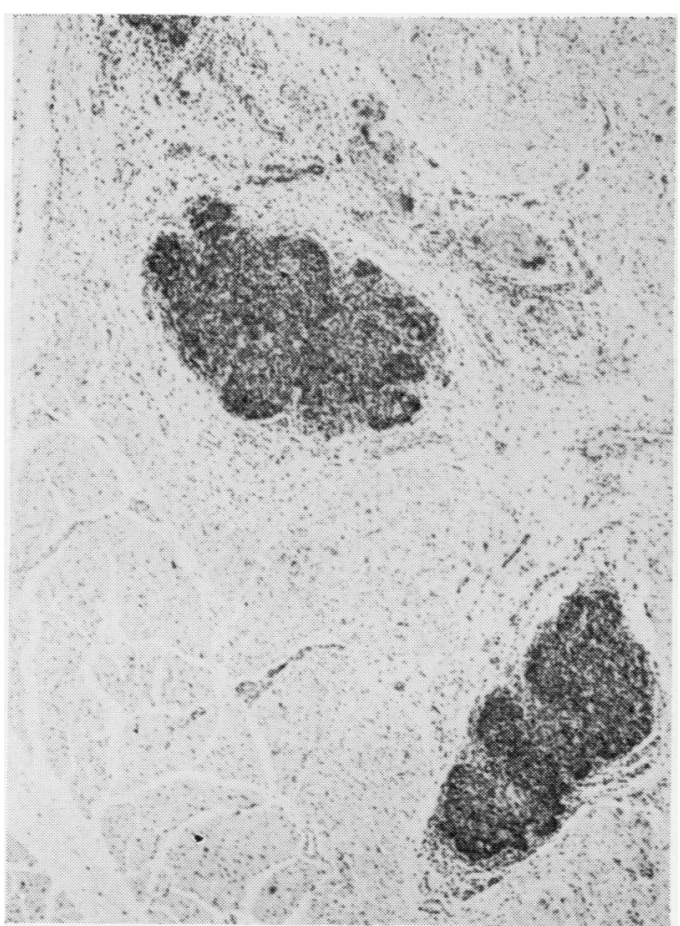

Fig. 6.

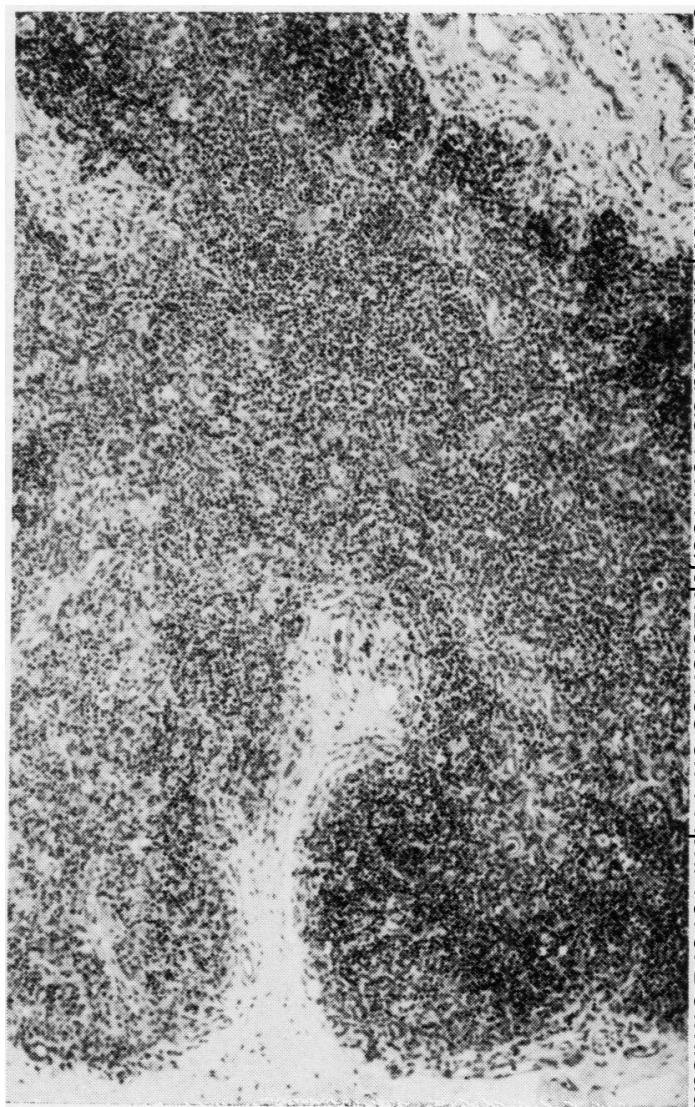

Fig. 5.

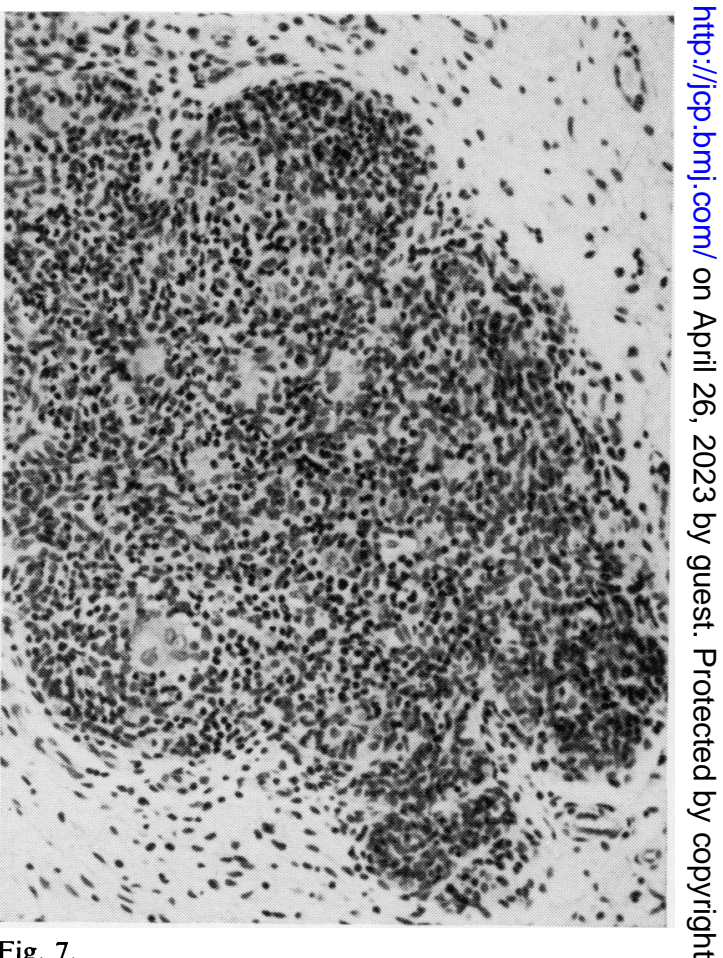




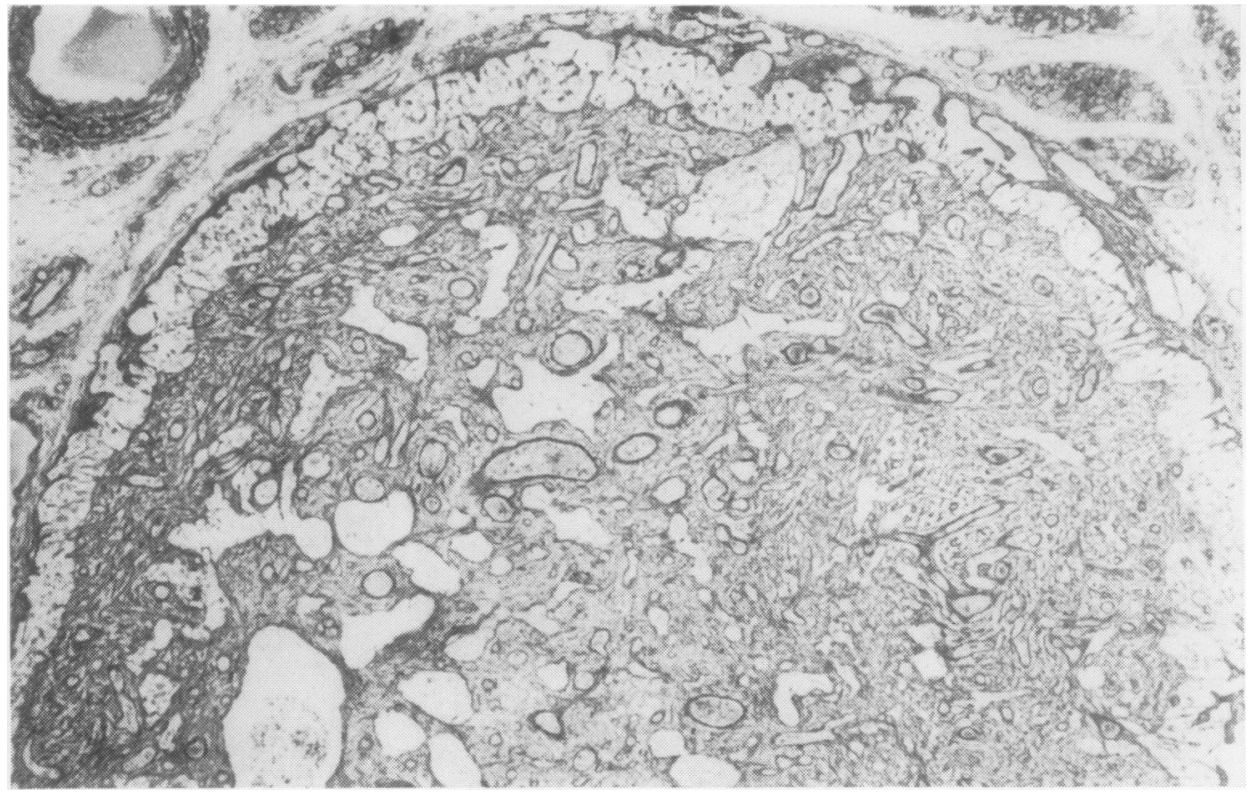

Fig. 8.

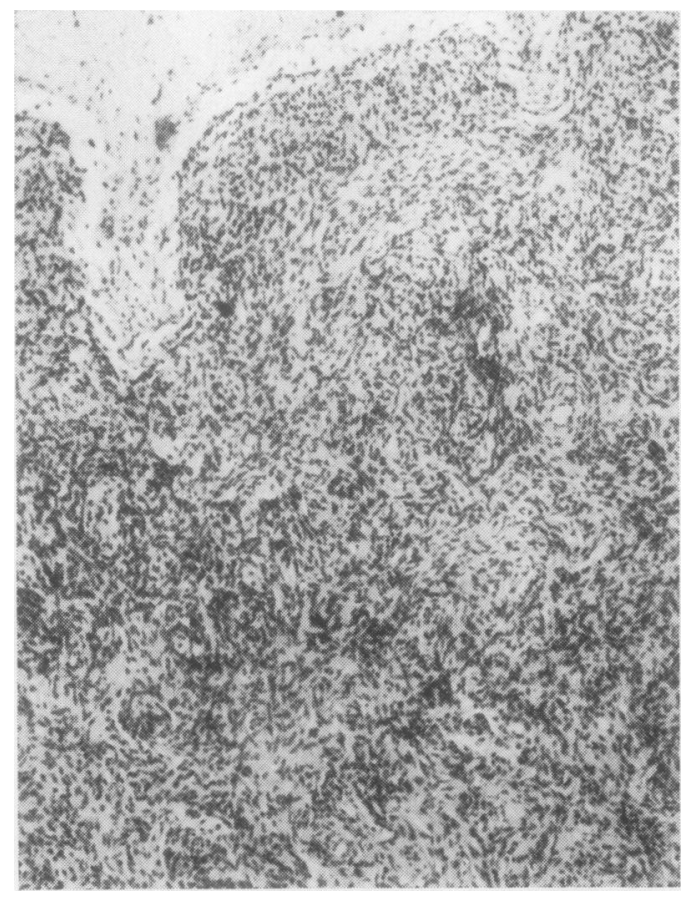

Fig. 9.

Fig. 8 Lymph node: reticulin structure. The subcapsular sinus is widely patent. Gordon and Sweet. $\times 50$.

Fig. 9 Lymph node: 'mesenchymal' appearance. Note the subcapsular sinus. $H \& E$. $\times 60$.

Fig. 10 Lymph node: occasional lymphocytes seen at the periphery of the node. $H \& E . \times 480$.

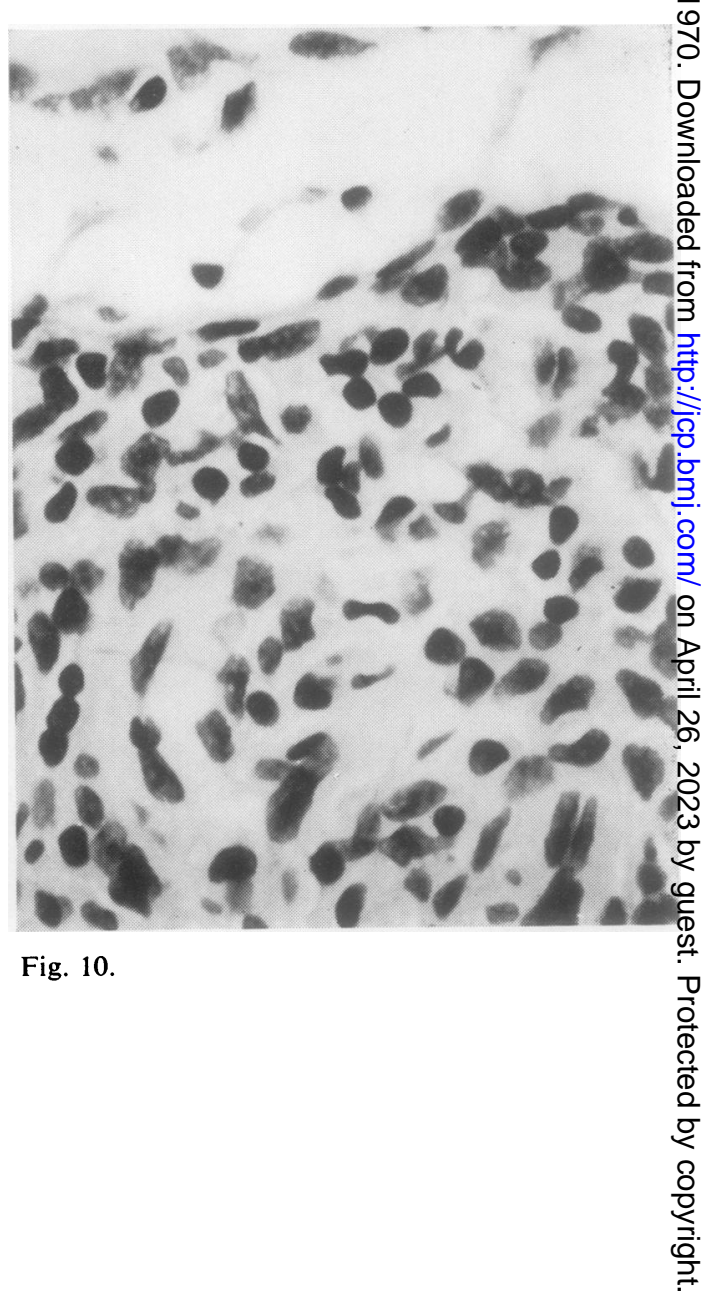




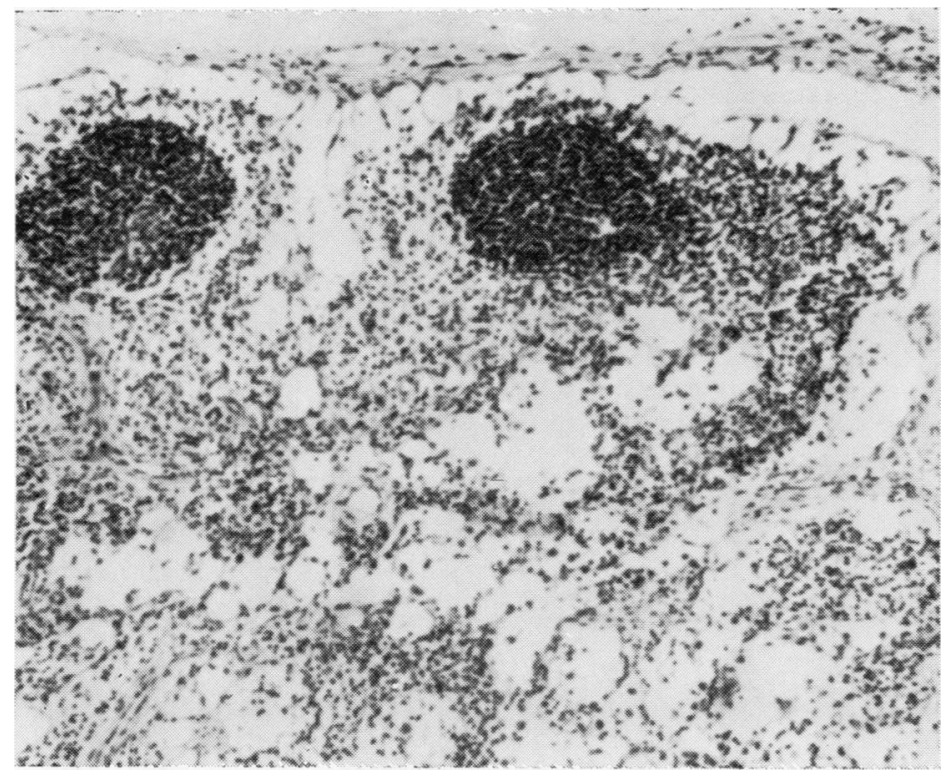

Fig. 11 Lymph node: follicular structures at the periphery of the node. $H \& E . \times 50$.

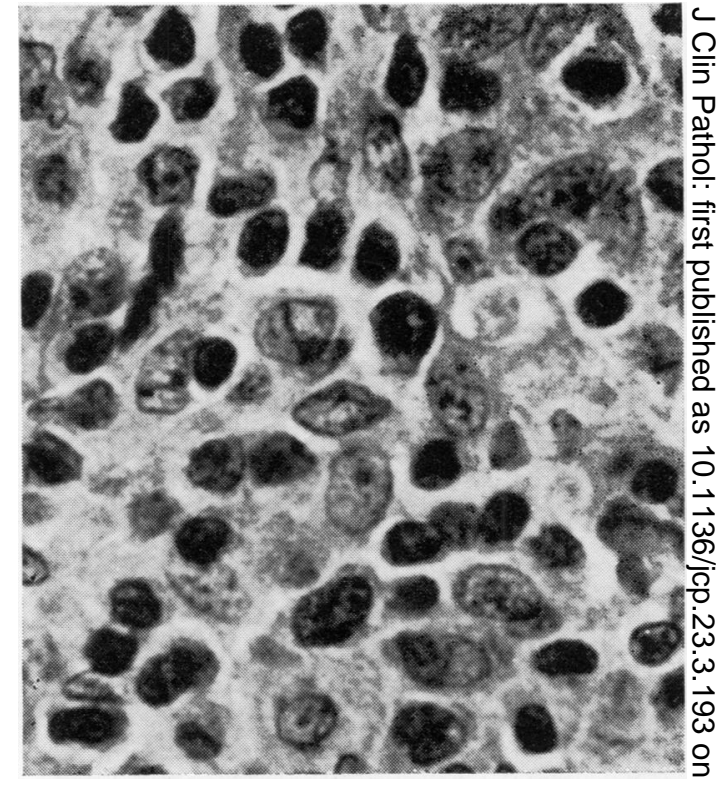

Fig. 12 Lymph node: large reticulum cells in node. $H \& E . \times 480$.

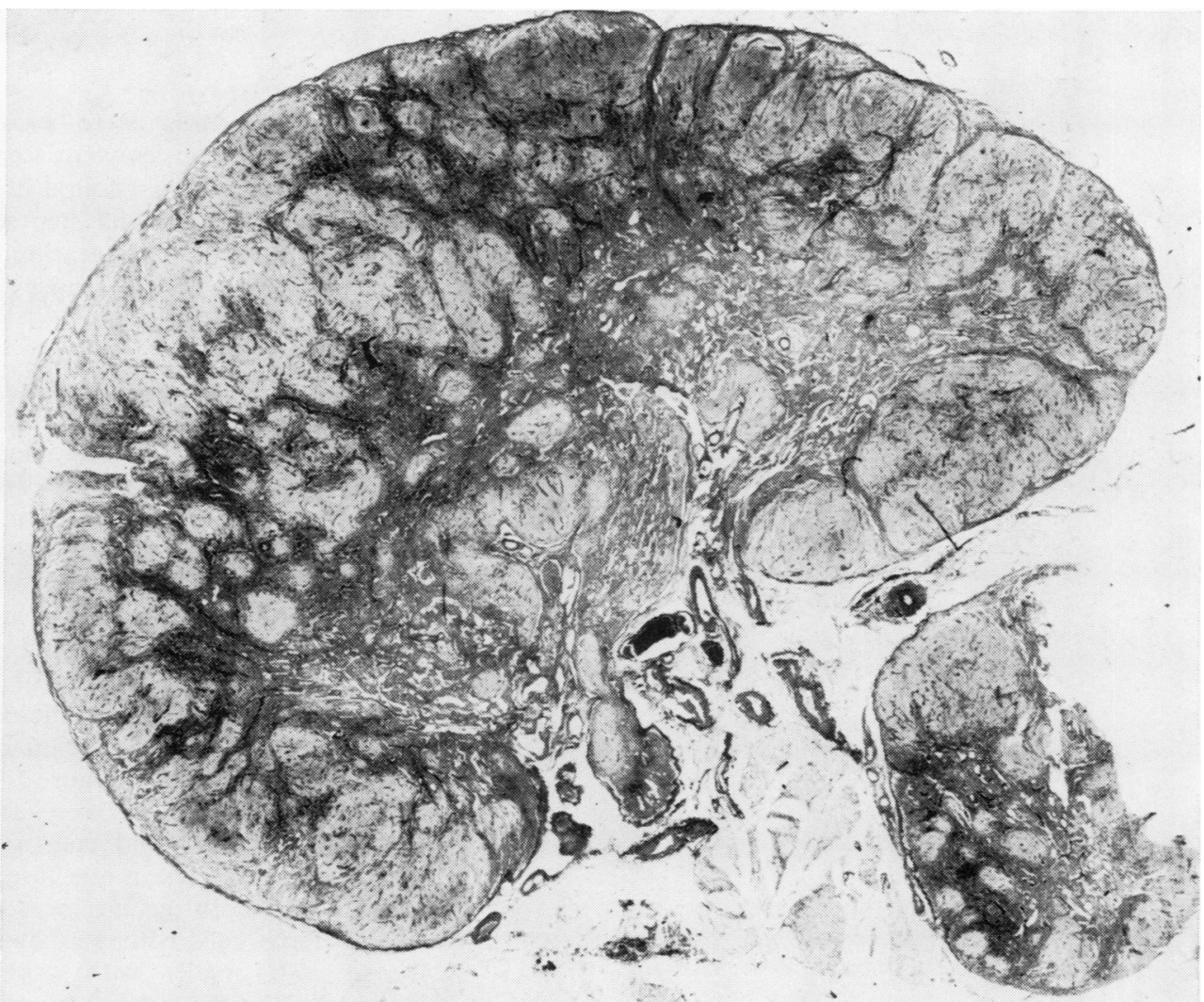

Fig. 13 Lymph node: reticulum pattern. Note the massive nodular proliferation of cells distorting the pattern, and poor development of the 'thymusdependent' zone. Gordon and Sweet. $\times 7$. 


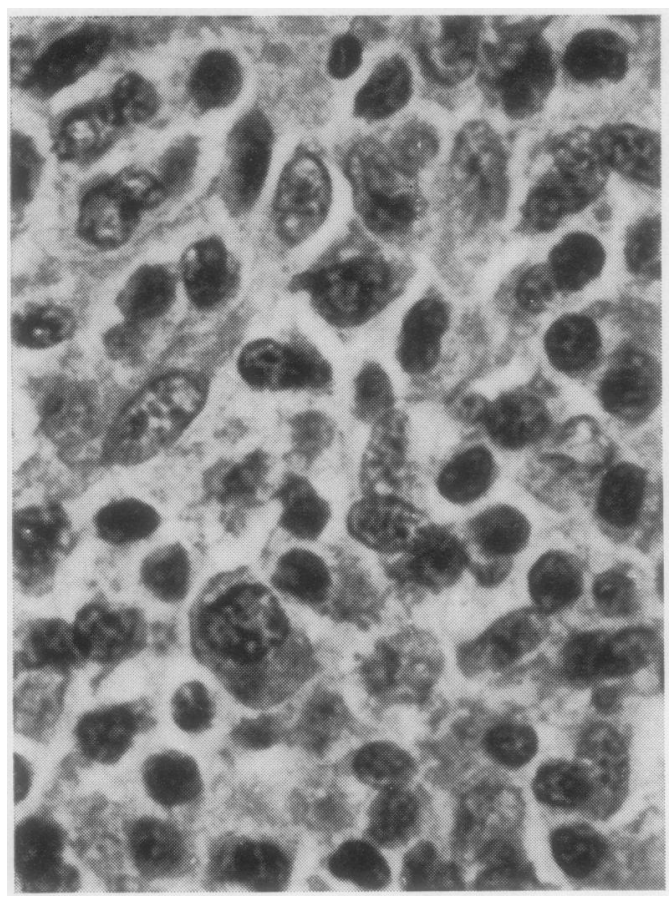

Fig. 14.

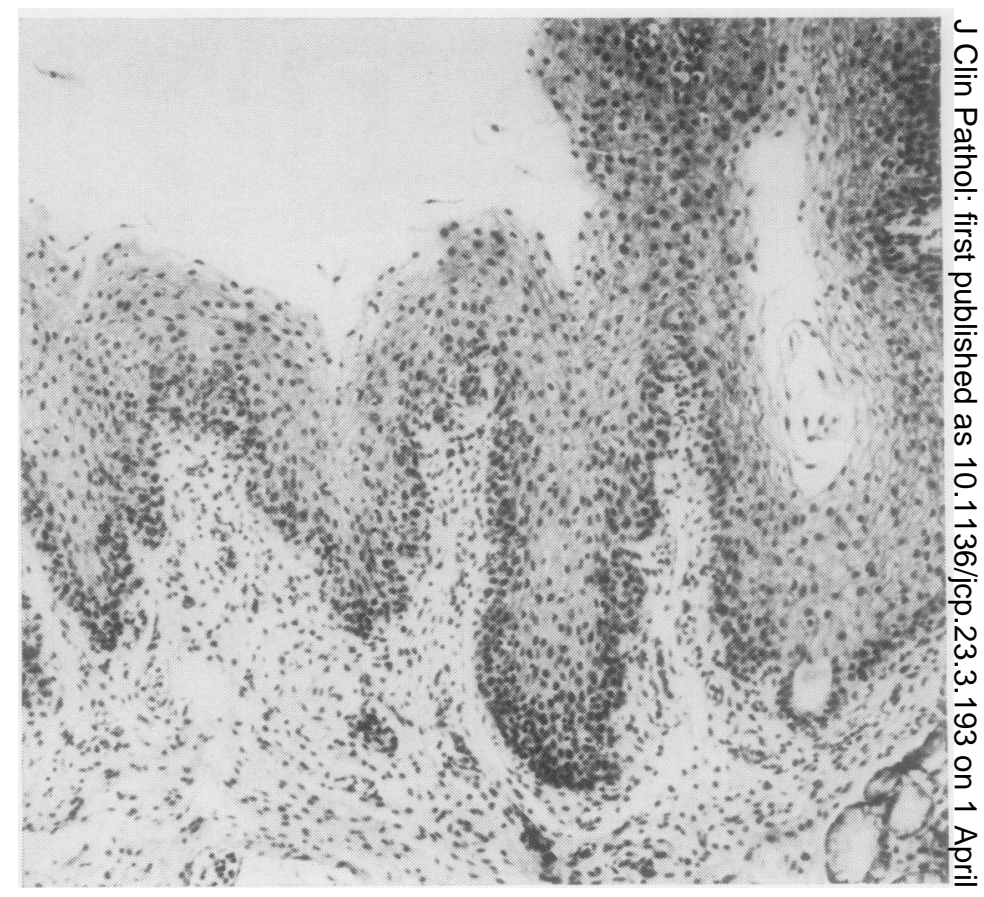

Fig. 15.

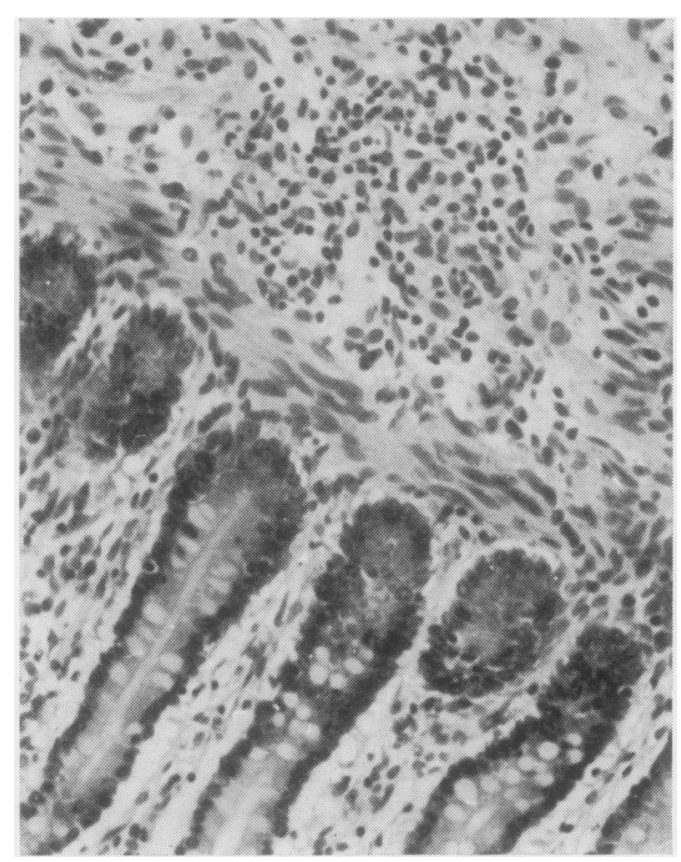

Fig. 16.

Fig. 14 Lymph node: large reticulum cells, some with atypical features in node. $H \& E . \times 480$.

Fig. 15 Tonsillar fossa: folded epithelium in tonsillar crypt. $H \& E$. $\times 40$.

Fig. 16 Colon: small collection of lymphocytes in the submucosa. The muscularis mucosa is not interrupted. $H \& E . \times 140$.
LYMPH NODES

Twenty-four cases were examined, in two, ٌ only surgical biopsies were seen. In four cases, $\stackrel{\varnothing}{\varnothing}$ lymph nodes were not found at necropsy despite $\overrightarrow{\vec{O}}$ an extensive search and step sectioning of the $\frac{3}{3}$ 'Swiss roll' type of preparation of the mesentery in two infants. Appearances in other cases? varied widely, but in general two main groups were found.

Group 1 consisted of essentially 'mesenchymal' 욱 nodes in which the reticulin pattern showed no evidence of distension of follicular proliferation of lymphocytes (Figure 8). These nodes often appeared to be masses of connective tissue and $\frac{\circ}{\square}$ were recognizable only by virture of the distinctive $\frac{D}{2}$ subcapsular sinus seen (Figure 9). The cellular populations of such nodes included few lympho- N cytes (Figure 10).

Group 2 included cases of nodes with well $\stackrel{N}{N}$ defined follicles in an otherwise 'hypoplastic' $\omega$ structure with a small cellular population and widely open sinusoids (Figure 11).

Intermediary forms were seen with varying numbers of lymphoid cells present, and both $\stackrel{?}{+}$ types might be seen in one case, but a prominent $\frac{T}{\overrightarrow{0}}$ feature in both groups was the presence of $\frac{\vec{D}}{\mathbb{D}}$ many large cells with abundant cytoplasm and $\stackrel{?}{?}$ large pale nuclei with prominent neucleoli, $\stackrel{\mathbb{Q}}{\varrho}$ presumed to be reticulum cells or histiocytes (Figure 12). These cells are of interest, since in 8 one case in which foetal thymus grafting and liver cell transfusion had been undertaken, axillary lymph nodes, previously impalpable, 


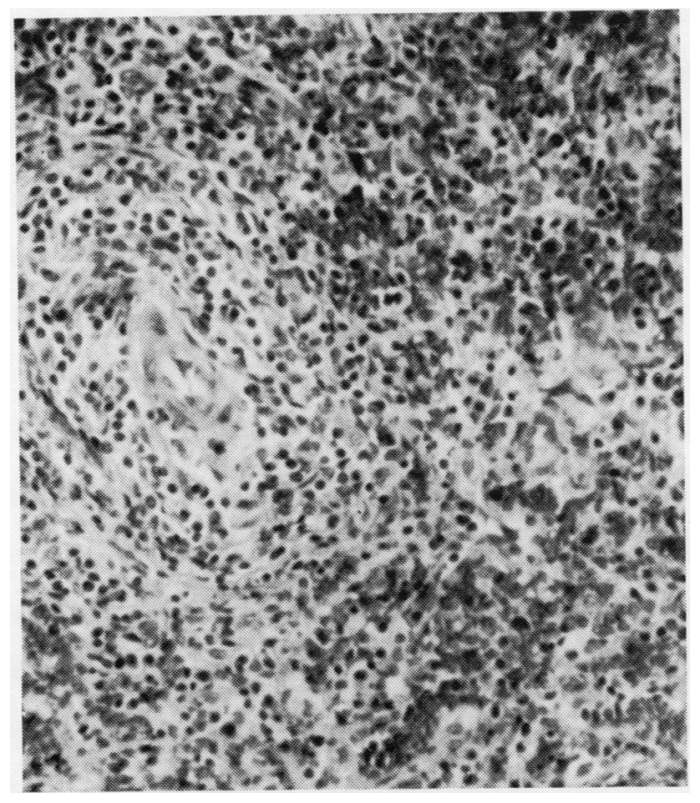

Fig. 17 Spleen: absence of perivascular lymphocyte cuffs. $H \& E$. $\times 160$.

had tecome readily palpable and enlarged. Histological sections had shown massive proliferation of such cells with distortion of normal nodal architecture (Figures 13 and 14).

Several nodes showed evidence of haemo-

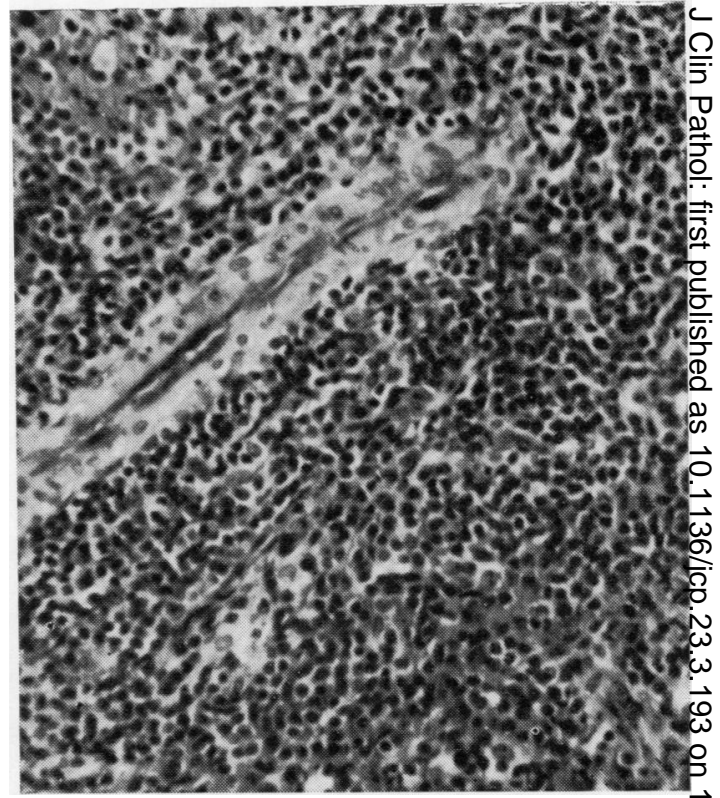

Fig. 18 Spleen: abundant perifollicular lymphocytes in splenic arteries. $H \& E . \times 160$.

phagocytosis. In no instance were two component 'reactive' follicles seen.

\section{GUT-ASSOCIATED LYMPHOID TISSUES}

Tonsil

Tonsils

\begin{tabular}{|c|c|c|c|c|}
\hline Case & $\begin{array}{l}\text { Splenic } \\
\text { Follicles }\end{array}$ & Lymph Nodes & $\begin{array}{l}\text { Lymphoid } \\
\text { Tissue in Gut }\end{array}$ & Tonsils \\
\hline 1 & Present & No nodes found & Absent & Atsent \\
\hline 2 & Present & No nodes found & Hypoplastic & Absent \\
\hline 3 & Not seen & No nodes found & Hypoplastic & Absent \\
\hline 4 & Hypoplastic & No follicles present & Hypoplastic & Hypoplastic \\
\hline 5 & Not seen & No follicles present & Hypoplastic & Hypoplastic \\
\hline 6 & Present & No nodes found & Hypoplastic & Hypoplastic \\
\hline 7 & Present & No nodes found & Present & Normal \\
\hline 8 & Present & $\begin{array}{l}\text { Single component follicles } \\
\text { present }\end{array}$ & Present & Normal \\
\hline 9 & Present & No follicles present & Present & Normal \\
\hline 10 & Present & No follicles present & Present & Normal \\
\hline 11 & Present & $\begin{array}{l}\text { Single component follicles } \\
\text { present }\end{array}$ & Present & Normal \\
\hline 12 & Present & No follicles present & Present & Normal \\
\hline 13 & Present & $\begin{array}{l}\text { Single component follicles } \\
\text { present }\end{array}$ & Present & \\
\hline 14 & Present & $\begin{array}{l}\text { Single component follicles } \\
\text { present }\end{array}$ & Present & Normal \\
\hline 15 & Not seen & $\begin{array}{l}\text { Single component follicles } \\
\text { present }\end{array}$ & $\begin{array}{l}\text { Hypoplastic } \\
\text { Present }\end{array}$ & Hypoplastic \\
\hline 16 & Not seen & $\begin{array}{l}\text { Single component follicles } \\
\text { present }\end{array}$ & Present & Hypoplastic \\
\hline 17 & Present & $\begin{array}{l}\text { Single component follicles } \\
\text { present }\end{array}$ & Present & Hypoplastic \\
\hline 18 & Present & $\begin{array}{l}\text { Single component follicles } \\
\text { present }\end{array}$ & Present & Hypoplastic \\
\hline $\begin{array}{l}19 \\
20\end{array}$ & $\begin{array}{l}\text { Present } \\
\text { Present }\end{array}$ & $\begin{array}{l}\text { No follicles present } \\
\text { Single component follicles } \\
\text { seen }\end{array}$ & $\begin{array}{l}\text { Present } \\
\text { Present }\end{array}$ & $\begin{array}{l}\text { Hypoplastic } \\
\text { Hypoplastic }\end{array}$ \\
\hline $\begin{array}{l}21 \\
22\end{array}$ & $\begin{array}{l}\text { Hypoplastic } \\
\text { Present }\end{array}$ & $\begin{array}{l}\text { No follicles present } \\
\text { No follicles present }\end{array}$ & $\begin{array}{l}\text { Present } \\
\text { Present }\end{array}$ & $\begin{array}{l}\text { Hypoplastic } \\
\text { Hypoplastic }\end{array}$ \\
\hline
\end{tabular}

Table I Findings in other lymphoid organs in 22 cases of thymic dysplasia seen at necropsy.
In three instances, tonsils were absent, witho sections showing folded crypt epithelium in the tonsillar fossa without evidence of lymphoido tissue (Figure 15). In four other instances hypo-plastic tonsils with small two-cell component follicular structures were present.

\section{Alimentary tract and appendix}

There was a constant association between $\frac{?}{2}$ lymphoid development of the alimentary tracte. and appendix and the tonsil; in no instance of tonsillar hypoplasia or agenesis was lymphoid tissue present in the gut in significant amounts (Figure 16). 'Significance' was considered to be ${ }^{\omega}$ present if the lymphoid tissue muscularis mucosak was breached by the collection of lymphoid tissue at the sites of Peyer's patches. The lamina propria in these cases was hypocellular, with absence of cells having plasma cell morphology.

\section{Spleen} the 22 cases examined was within the normak weight range for the age. Histological appearances varied with sinusoidal hyperplasia and erythro phagocytosis, seen in some instances in whicla lymphocytes were scanty (Fig. 17), and lympho?
In all cases the spleen was present, and in all of 
cytic perivascular cuffs and follicles seen in other cases (Figure 18).

A summary of histopathological findings in the 22 cases in which all tissues were examined is given in the Table.

\section{Discussion}

The 'high' position of the thymus in this syndrome has previously been commented on by Miller and Schieken (1967) who pointed out that the thymic remnant might be associated with the thyroid gland. This positional defect is presumably related to abnormal development of the third and fourth branchial arches, seen in its most severe form in thymic aplasia, with absent parathyroids, and with associated anomalies of the aortic arches (Dische, 1968).

The uniformity of histological appearance in the thymus in cases of thymic dysplasia is evident from previous reports (Tobler and Cottier, 1958; Gitlin and Craig, 1963; Gitlin, Vawter, and Craig, 1964; Berry and Thompson, 1968). In a light and electron microscopic study of four cases, Blackburn and Gordon (1967) also commented upon the uniformity of histological appearances, and mentioned the interesting point, also noted in the present series, that connective tissue stains revealed 'less collagen than would have been expected after viewing haematoxylin and eosin preparations' in the thymic lobules. Blackburn and Gordon also illustrated the glandular appearance of the lobules of the dysplastic gland and showed the component cells of this region to be epithelial in origin. They suggested that the appearances of the thymus were consistent with an arrest in development at the $30 \mathrm{~mm}$ stage, at which time corticomedullary demarcation in the human foetus becomes apparent. They considered that arrest had occurred at a stage immediately following penetration of the epithelial primordium by mesenchyme but before lymphoid differentiation.

It was in order to assess this point that aborted foetuses were examined, and a study of the thymic medulla was undertaken so as to assess the normal rate of development of the epithelial component of the thymus gland. The development of Hassall's corpuscle-like structures was preceded by the accumulation of mononuclear cells, which formed aggregates in the developing medulla of the gland (Figure 19). The cells then developed cytoplasmic inclusions in their cytoplasm, and Hassall's corpuscles gradually developed by coalescence within such cell masses.

It was found that in this group of foetuses, in which crown/rump length had been measured before fixation, the stage at which such mononuclear cells appeared in the thymic medulla varied considerably, as did the development of Hassall's corpuscles. In general, however, it

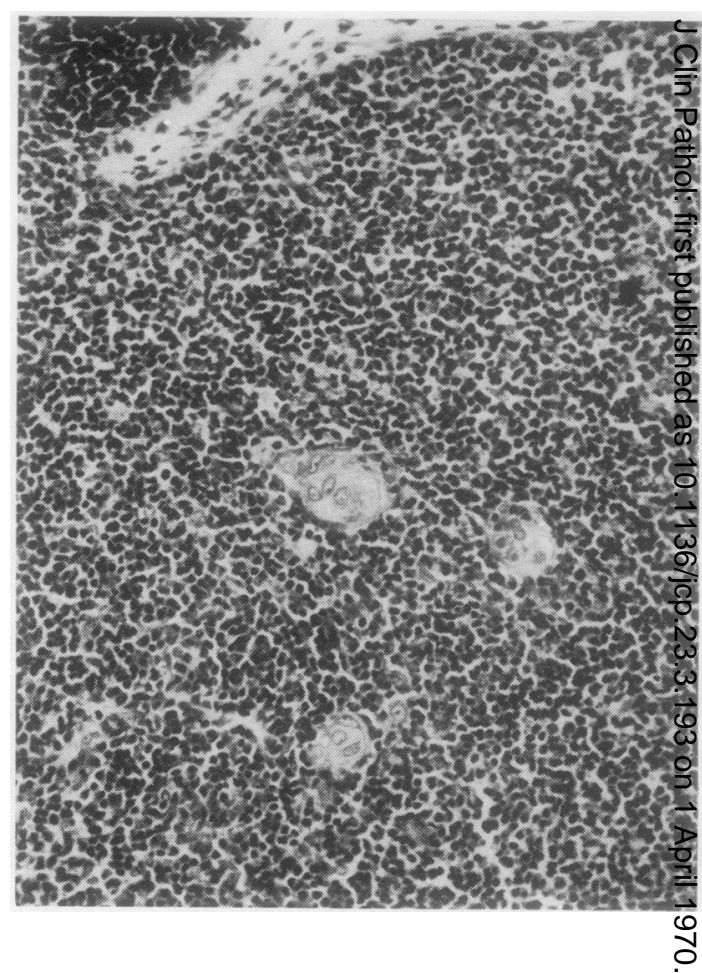

Fig. 19 Foetal thymus: mononuclear cell aggregates with fusion of cells. $H \& E$. $\times 120$.

could be said that some evidence of thymię epithelial differentiation was present before $65 \mathrm{~mm} \overrightarrow{\overrightarrow{0}}$ in the normal gland, and Hassall's corpuscle ${ }^{3}$ might be present by $70 \mathrm{~mm}$, but were occasionally not present at the $100 \mathrm{~mm}$ stage.

Blackburn and Gordon (1967) had suggestecक that there was an endodermal failure in develop:ment in these cases, and that the anomaly in thymic alymphoplasia was related to absence of Hassall's corpuscles. In a previous study (Berry, 1968), using the numbers of Hassall'so corpuscles as an index of thymic epitheliaP development, the author has been able to selecto cases of the combined immunity deficiency syndrome from a blind study of a necropsyo series. This finding supports the view that an defect in thymic epithelial maturation is of fundamental importance in the genesis of thymic ${ }^{\omega}$ dysplasia, but that possibly the abnormality may develop later than suggested by Blackburne and Gordon (1967).

The presence of large mononuclear cells in two cases, although not in aggregates, mayo indicate a less severe degree of anomaly. In both instances in which these cells were present, $\frac{?}{\mathbb{P}}$ organized lymphoid tissue was seen in the gut, and follicular structures were present in the spleen and lymph nodes.

Reconstitution therapy at this hospital has involved the transplantation of foetal thymusc. and transfusion of foetal liver cells in an attempt? 


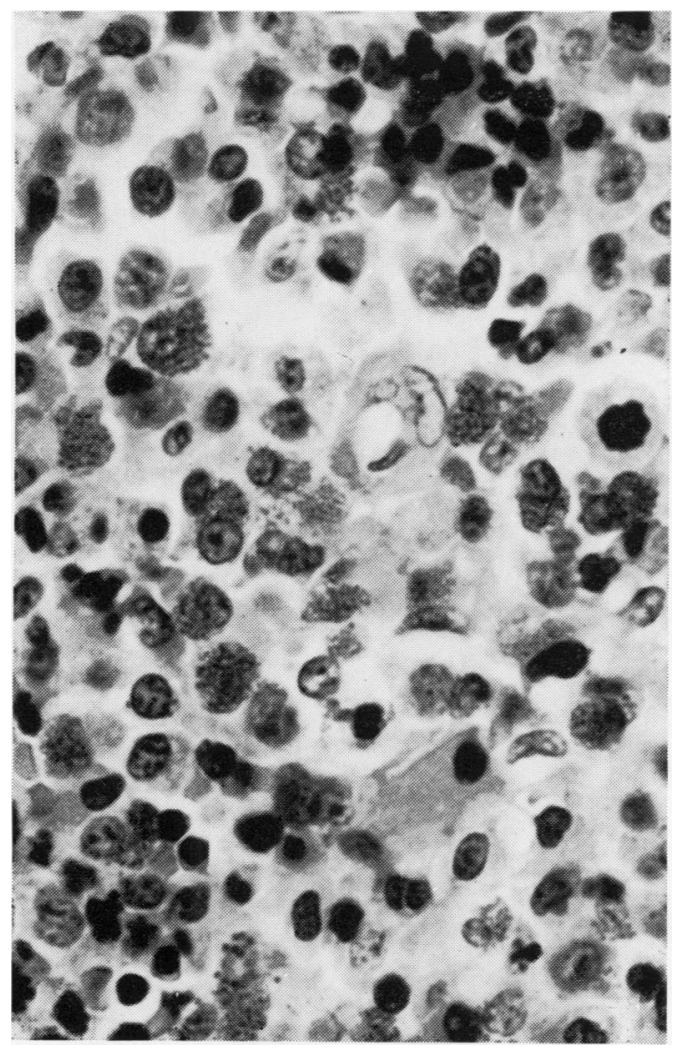

Fig. 20 Bone marrow: proliferation of reticulum cells and eosinophils. $H \& E . \times 480$.

to repair a thymic defect and to supply stem cells. Thymic grafts may survive in these circumstances and maintain architectural and cytological patterns consistent with the stage of development that would have been reached in the period of gestation plus the time elapsed since grafting. The presence of mononuclear cell aggregates in the grafted thymus (see Fig. 7), removed from a $63 \mathrm{~mm}$ embryo, suggests that functional epithelial elements were present in this gland, and may relate to the appearance of lymph node enlargement, increase in peripheral lymphocyte count, and histological changes suggesting active proliferation of cells in lymph nodes and bone marrow.

Other attempts at grafting in this syndrome have generally been unsuccessful (see Kretschmer, Jeannet, Mereu, Kretschmer, Winn, and Rosen, 1969, for a bibliography), although reports of some success in this field have been made recently (de Koning, Dooren, van Bekkum, van Rood, Dicke, and Rádl, 1969). Nevertheless, the alteration in nodal histology seen in our case, together with the massive proliferation of histiocyte-like cells and eosinophils in the bone marrow (Fig. 20), is apparently unique.

The essential variability in the histological appearances of lymph nodes in these cases is $c$ remarkable. A range of changes, including $\subseteq$ complete absence, gross hypoplasia, and some $\overline{\bar{F}}$ hypoplasia with primary follicle formation, is seen. No strict correlation of severity of change $\bar{\partial}$ with duration of disease is seen, but those cases with absent lymph nodes tended to die earlier than the rest of the group (Berry and Thompson, 1968). Haemophagocytosis seen in five cases was severe in one instance in which the degree of change was reminiscent of familial haemophagocytic reticulosis (Farquhar and Claireaux, 1952). The proliferation of cells in the patient receiving 5 the thymic transplant resembles reticulum-cell $\vec{\circ}$ sarcoma in some respects, and is of interest $\overrightarrow{\vec{J}}$ in view of the higher incidence of this neoplasm $\stackrel{\omega}{\circ}$ in patients with immune deficiency states, and in patients undergoing immuno-suppressive therapy (Deodhar, Kuklinca, Vidt, Robertson, and $\omega$ Hazard, 1969). Reticulum cell hyperplasia has been noted in lymphoid organs following transplantation (Standen, Esterly, and Pearson, 1969).

The severity of splenic changes showed no correlation with the severity of the disease. In one instance, however, that case in which remarkable haemophagocytosis was seen in the lymph nodes, the splenic pulp contained large numbers of reticulum cells stuffed with red cells, and the child was noted to have a haemolytic anaemia clinically.

The finding of a constant association of hypoplasia of the tonsil with absent or grossly $\stackrel{\varnothing}{\varrho}$ deficient lymphoid tissue at various sites in the $\overrightarrow{\vec{O}}$ gut is strong supportive evidence for the hypothesis proposed and verified by Cooper, Perey, McKneally, Gabrielsen, Sutherland, and Good (1966), Perey and Good (1968), and Perey, Cooper, and Good (1968) that such tissues represent a distinct lymphoid organ in mammals, possibly the equivalent of the avian bursa of Fabricius. These tissues should be concerned with the development of humoral rather than cellular immunity. In the six cases in which tonsillar hypoplasia has been present in this series, however, $\frac{I}{O}$ immunoglobulin levels have been normal or high in two. It is of course true that histological o assessment of hypoplasia is a crude method of $N$ assessment of the potential function of an organ, $N$ and the possibility that all immuno-chemically determined immunoglobulin molecules may not be functioning antibody must be considered.

The sections from therapeutic abortions were made available by Dr H. E. M. Kay, the Royal Marsden Hospital, London.

\section{References}

Berry, C. L. (1968). The neonatal thymus and immune paresis Proc. roy. Soc. Med., 61, 867-871.

Berry, C. L., and Thompson, E. N. (1968). Clinico-pathological study of thymic dysplasia. Arch. Dis. Childh., 43, 579-584. 
Blackburn, W. R., and Gordon, D. S. (1967). The thymic remnant in thymic alymphoplasia: light and electron microscopic studies. Arch. Path., 84, 363-375.

Cooper, M. D., Perey, D. Y., McKneally, M. F., Gabrielsen, A. E., Sutherland, D. E. R., and Good, R. A. (1966). A mammalian equivalent of the avian-bursa of Fabricius. Lancet, 1, 1388-1391.

Deodhar, S. D., Kuklinca, A. G., Vidt, D. G., Robertson, A. L. and Hazard, J. B. (1969). Development of reticulum-cell sarcoma at the site of antilymphocyte globulin injection in a patient with renal transplant. New Engl. J. Med. 280, 1104-1106.

Dische, M. R. (1968). Lymphoid tissue and associated congenital malformations in thymic agenesis. Arch. Path., 86, 312-316.

Farquhar, J. W., and Claireaux, A. E. (1952). Familial haemophagocytic reticulosis. Arch. Dis. Childh., 27, 519-525.

Gitlin, D., and Craig, J. M. (1963). The thymus and other lymphoid tissues in congenital agammaglobulinemia. I. Thymic alymphoplasia and lymphocytic hypoplasia and their relation to infection. Pediatrics, 32, 517-530.

Gitlin, D., Vawter, G., and Craig, J. M. (1964). Thymic alymphoplasia and congenital alenkocytosis. Pediatrics, 33, 184-192.

Glanzmann, E., and Riniker, P. (1950). Essentielle Lymphocytophthise. Ein neues krankheitsbild aus der Säuglingspathologie. Ann. Pédiat., 175, 1-32.

de Koning, J., Dooren, L. J., van Bekkum, D. W., van Rood, J. J., Dicke, K. A., and Rádl, J. (1969). Transplantation of bone-marrow cells and fetal thymus in an infarct with lymphopenic immunological deficiency. Lancet, 1, 12231227.
Kretschmer, R., Jeannet, M., Mereu, T. R., Kretschmer, Kc Winn, H., and Rosen, F. S. (1969). Hereditary thymig dysplasia: a graft-versus-host reaction induced by bone. marrow cells with a partial 4 a series histoincompatibility? Paed. Res., 3, 34-40.

Miller, M. E., and Schieken, R. M. (1967). Thymic dysplasia: ஹ્ષ્మ separable entity from 'Swiss agammaglobulinemia' Amer. J. Med. Sci., 253, 741-750.

Perey, D. Y. E. and Good, R. A. (1968). Experimental arrest and induction of lymphoid development in intestinas lymphoepithelial tissues of rabbits. Lab. Invest., 18 15-26.

Perey, D. Y. E., Cooper, M. D., and Good, R. A. (1968). Lyn高 phoepithelial tissues of the intestine and differentiation antibody production. Science, 161, 265-266.

Standen, A. C., Esterly, J. R., ard Pearson, B. (1969). Reticulæ cell response to transplants: reactive changes in the rabbidy Arch.Path., 87, 5762.

Tobler, R., and Cottier, H. (1958). Familiäre Lymphopenie mit Agammaglobulinämie und schwerer moniliasis. Hel? pediat. Acta, 13, 313-338. 